University of Chicago Law School

Chicago Unbound

Journal Articles

Faculty Scholarship

1992

\title{
Legal Reasoning from the Top Down and from the Bottom Up: The Question of Unenumerated Constitutional Rights
}

Richard A. Posner

Follow this and additional works at: https://chicagounbound.uchicago.edu/journal_articles

Part of the Law Commons

\section{Recommended Citation}

Richard A. Posner, "Legal Reasoning from the Top Down and from the Bottom Up: The Question of Unenumerated Constitutional Rights," 59 University of Chicago Law Review 433 (1992).

This Article is brought to you for free and open access by the Faculty Scholarship at Chicago Unbound. It has been accepted for inclusion in Journal Articles by an authorized administrator of Chicago Unbound. For more information, please contact unbound@law.uchicago.edu. 


\title{
Legal Reasoning From the Top Down and From the Bottom Up: The Question of Unenumerated Constitutional Rights
}

\author{
Richard A. Posnert
}

\section{Top-Down and Botrom-Up Reasoning}

I want to approach the subject of my debate with Professor Dworkin - unenumerated constitutional rights-by distinguishing two types of legal reasoning: what I shall call reasoning from the top down and reasoning from the bottom up. In top-down reasoning, the judge or other legal analyst invents or adopts a theory about an area of law-perhaps about all law-and uses it to organize, criticize, accept or reject, explain or explain away, distinguish or amplify the existing decisions to make them conform to the theory and generate an outcome in each new case as it arises that will be consistent with the theory and with the canonical cases, that is, the cases accepted as authoritative within the theory. The theory need not be, perhaps never can be, drawn "from" law; it surely need not be articulated in lawyers' jargon. In bottom-up reasoning, which encompasses such familiar lawyers' techniques as "plain meaning" and "reasoning by analogy," one starts with the words of a statute or other enactment, or with a case or a mass of cases, and moves from there-but doesn't move far, as we shall see. The topdowner and the bottom-upper do not meet.

I am associated with several top-down theories. One, which is primarily positive (descriptive), is that the common law is best understood on the "as if" assumption that judges try to maximize the wealth of society. Another, primarily normative, is that judges should interpret the antitrust statutes to make them conform to the dictates of wealth maximization. In the development of the lat-

† Judge, United States Court of Appeals for the Seventh Circuit; Senior Lecturer, The University of Chicago Law School. This is a slightly expanded text of my talk at The Bill of Rights in the Welfare State: A Bicentennial Symposium, held at The University of Chicago Law School on October 25-26, 1991. The reader should bear in mind that it was prepared for oral delivery. I thank Ronald Dworkin, Frank Easterbrook, Lawrence Lessig, Andrew Schapiro, and Cass Sunstein for many helpful comments. 
ter theory, Robert Bork-Dworkin's bete noire ${ }^{1}$-was a pioneer. Bork called his theory "consumer welfare maximization,"' but that is just a reassuring term for wealth maximization. He divided the Supreme Court's antitrust cases into a main tradition informed by the principles of wealth maximization and a deviant branch of that tradition, and he argued for lopping off the branch. ${ }^{3}$

Dworkin himself is prominently associated with a theory of constitutional law that makes such law the expression of liberalism, weighted with egalitarianism. ${ }^{4}$ Richard Epstein has a broadly similar view of constitutional law but he weights his liberalism not with egalitarianism but with economic freedom. ${ }^{5} \mathrm{John}$ Hart Ely has a different but equally ambitious theory of constitutional law, one that yokes the various clauses together to draw the plow called promoting the values of a representative democracy. ${ }^{6}$ Bruce Ackerman has still another. ${ }^{7}$ A famous common-law topdowner from an earlier generation was Christopher Columbus Langdell. ${ }^{8}$ And before him Hobbes.

Yet legal reasoning from the bottom up is the more familiar, even the more hallowed, type. ${ }^{9}$ The endlessly repeated refrain of modern judicial opinions that in interpreting a statute the judge must start with its words is in this tradition. And we all remember our first day in law school, when we were asked to read for each course not an overview or theoretical treatment of the field but a case-a case, moreover, lying in the middle rather than at the historical or logical beginning of the field. Those of us who are judges also remember our first day in that job, when we were handed a

'See the following works by Ronald Dworkin: Reagan's Justice, NY Rev Books 27 (Nov 8, 1984); The Bork Nomination, NY Rev Books 3 (Aug 13, 1987); From Bork to Kennedy, NY Rev Books 36 (Dec 17, 1987); and Bork's Jurisprudence, 57 U Chi L Rev 657 (1990).

${ }^{2}$ Robert H. Bork, The Antitrust Paradox: A Policy at War With Itself 7 (Basic, 1978) ("the only legitimate goal of antitrust is the maximization of consumer welfare").

${ }^{3}$ See Robert H. Bork, The Rule of Reason and the Per Se Concept: Price Fixing and Market Division (Part I), 74 Yale L J 775 (1965); Robert H. Bork, The Rule of Reason and the Per Se Concept: Price Fixing and Market Division (Part II), 75 Yale L J 375 (1966).

+ See, for example, Ronald Dworkin, Taking Rights Seriously (Harvard, 1977).

${ }^{5}$ See, for example, Richard A. Epstein, Property, Speech and the Politics of Distrust, 59 U Chi L Rev 41 (1992).

' See John Hart Ely, Democracy and Distrust: A Theory of Judicial Review (Harvard, 1980).

' See, for example, Bruce Ackerman, We the People: Foundations (Belknap, 1991).

- See, for example, Christopher Columbus Langdell, A Selection of Cases on the Law of Contracts (Little Brown, 1871) (preface).

- For a classic statement, see Edward H. Levi, An Introduction to Legal Reasoning (Chicago, 1949). 
sheaf of briefs in cases from fields we may have known nothing about and told that in a few days we would be hearing oral argument and would then take our tentative vote.

There is a question whether legal reasoning from the bottom up amounts to much. Dworkin thinks not. His extensive writings evince little interest in the words of the Constitution, or in its structure (that is, in how its various parts-the articles, sections, clauses, and amendments-work together), in the texture and details of the complex statutes that his works discuss, such as Title VII of the Civil Rights Act of $1964,{ }^{10}$ or in any extended body of case law, let alone in the details of particular cases. His implicit legal universe consists of a handful of general principles embodied in a handful of exemplary, often rather bodiless, cases.

I do not myself see the law in quite that way but I agree there isn't much to bottom-up reasoning. ${ }^{11}$ We don't ever really "start" from a mass of cases or from a statute or from a clause of the Constitution. To read a case, to read a statute, a rule, or a constitutional clause presupposes a vast linguistic, cultural, and conceptual apparatus. And more: You don't see judicial opinions that say, for example, "On page 532 of Title 29 of the U.S. Code appears the following sentence ...." The opinion invariably gives you the name of the statute ("The Sherman Act provides . . ." or "ERISA provides . ..") and immediately you are primed to react to the words in a particular way. And if, as is so common, the case or statute or other enactment is unclear, and maybe even when it seems quite clear, the reader, to extract or more precisely to impute its meaning, must interpret it; and interpretation, we now know, is as much creation as discovery.

Nor is it clear what it means to reason "from" one case to another, the heart of bottom-up reasoning in law. It sounds like induction, which from Hume to Popper has taken hard knocks from philosophers. Actually, most reasoning by analogy in law is an oblique form of logical reasoning. Cases are used as sources of interesting facts and ideas, and hence as materials for the creation of a theory that can be applied deductively to a new case. But not as the exclusive materials for the creation of the theory; that would unjustifiably exclude whole worlds of other learning and insight.

Reasoning by analogy also has an empirical function. If case A is canonical within your theory, and along comes case $B$, and the theory implies that the outcome of $\mathrm{B}$ should be different from $\mathrm{A}$,

10 Ronald Dworkin, A Matter of Principle 316-31 (Harvard, 1985).

"See Richard A. Posner, The Problems of Jurisprudence ch 2 (Harvard, 1990). 
you had better be sure that the two outcomes are logically consistent; otherwise you have a problem with the theory. So cases accepted within a theory provide testing instances for its further application. But there must be a theory. You can't just go from case to case, not responsibly anyway. You can't say: I have no theory of privacy or due process or anything else, but, given Griswold, ${ }^{12}$ $R_{0}{ }^{13}$ follows. You have to be able to say what in Griswold dictates Roe. Griswold doesn't tell you how broadly or narrowly to read Griswold.

\section{Unenumerated Rights and the Two Methods of REAsoning}

All this may be too compressed to carry conviction. But I'm not centrally interested here in showing the limitations of bottomup reasoning. I am more interested in reminding you of its established place in our legal tradition and in relating it to the issue of unenumerated rights. The relation is this. The issue of unenumerated rights looks quite different when you approach it bottom up than when you approach it from the top down.

Start with top-down. If we wanted to take a top-down approach to the Constitution we might proceed as have Dworkin, and Epstein, and Ely, and many others, each in his own way, by creating from a variety of sources-the text, history, and background of the Constitution (with the text given no particular primacy, because people who are sophisticated about interpretation know that text doesn't come first in any illuminating sense), the decisions interpreting the Constitution, and sundry political, moral, and institutional values and insights-a comprehensive theory of the rights that the Constitution should be deemed to recognize. Armed with such a theory one can select a main tradition of cases and discard or downplay the outliers and thus decide new cases in a way that will be consistent both with the theory and with the (duly pruned) precedents.

If I were to attempt such a project I might come out a good deal closer to Professor Dworkin than many in this audience would think possible. I consider myself a liberal, albeit in the classical tradition, the tradition of John Stuart Mill, Herbert Spencer, and Milton Friedman, rather than in the newer, welfarist or redistributive sense pioneered by John Rawls; and if I weight economic free-

\footnotetext{
${ }^{12}$ Griswold v Connecticut, 381 US 479 (1965).

${ }^{13}$ Roe v Wade, 410 US 113 (1973).
} 
dom more and equality less than Dworkin, and perhaps, owing to a different temperament, to different experiences in the law, or whatever, would be more timid than he about assertions of judicial power and more inclined than he to give the states room for experimentation, the practical differences might be small, especially in the areas of personal rights such as freedom of speech, religious freedom, and sexual and reproductive liberty. And then indeed, as Dworkin says in the very interesting article that he has prepared for this debate, the right to use contraceptives and the right to burn the American flag (provided you own the flag you burn) would be seen to stand on the same plane as far as the distinction between enumerated and unenumerated rights is concerned. ${ }^{\mathbf{1 4}}$

The distinction has no significance to a comprehensive constitutional theory. The theory may use the text as one of its jumpingoff points (one of, not the), but it goes beyond and eventually submerges textual distinctions, because, on the approach I am describing, specific constitutional rights such as the right to burn flags or to use contraceptives come out of the theory rather than (directly) out of the text.

The situation is different if you follow a bottom-up approach. For then you start by paging through the Constitution and you will find nothing that seems related to contraception, sex, reproduction, or the family. You will find no mention of the flag either but you will find a reference to freedom of speech, and it is easy to move analogically from literal speech to flag burning, as in the following interior Socratic dialogue:

"I see nothing here about flags or about the use of fire. Speech is verbal. Flag-burning is not a verbal act."

"Well, to begin, must speech be oral? Is sign language speech? If so, doesn't this show that speech goes beyond words, to include gestures? And what about communicating with semaphores? Semaphores are flags, as a matter of fact."

"I fully agree that sign language and semaphores are speech, but they are merely different methods from spoken language of encoding words-as is Morse code, or writing itself."

"Since we're talking about the flag-burning issue, what about the chain of . fires that in Aeschylus's great play Aga-

"Ronald Dworkin, Unenumerated Rights: How and Whether Roe Should be Overruled, 59 U Chi L Rev 381, 388-89 (1992). 
memnon are used to signal the fall of Troy to Clytemnestra hundreds of miles away?"

"Well, that's not quite speech because the fires don't encode a particular form of words, but they do communicate a simple message."

"Is the essence of constitutionally protected speech, then, the communication of a message?"

"Yes."

"So the signal fires would be protected (provided there were no safety concerns, etc.)?"

"Surely."

"But doesn't flag-burning, when employed as an element of a protest or a demonstration rather than as a method of discarding a piece of worn-out cloth or starting a (literal) conflagration, communicate a message?"

"Well, I suppose so, but it involves the destruction of property and that's different."

"People are allowed to destroy their own property, aren't they? And this isn't wanton destruction; it's consumption; it's just like the destruction of a forest to produce the Sunday New York Times. Isn't it?"

"I guess you're right."

This method of "proof" may well be spurious. It shows that there is a sense of "speech" that embraces flag burning-just as there is a sense of the word that embraces a right of association and a right not to be forced to express support for a cause one disfavors. ${ }^{15}$ But it doesn't furnish a reason for adopting that sense rather than a narrower one. For that, one must range wider and consider the differences, not just the similarities, between burning a flag and engaging in the other forms of communication that the courts have held to be constitutionally protected. One must, in fact, develop or adopt a theory of free speech and then apply it to the case at hand. The development of such a theory was Bork's project in his famous 1971 Indiana Law Journal piece, ${ }^{16}$ which he later retracted in part. ${ }^{17}$

\footnotetext{
${ }^{15}$ See NAACP v Alabama, 357 US 449, 460 (1958); West Virginia State Board of Education v Barnette, 319 US 624, 633 (1943).

${ }_{18}$ Robert H. Bork, Neutral Principles and Some First Amendment Problems, 47 Ind L J I (1971).

${ }_{17}$ Nomination of Robert H. Bork to be Associate Justice of the Supreme Court of the United States, Hearings Before the Senate Committee on the Judiciary, 100th Cong, 1st Sess 269-71 (Sep 16, 1987).
} 


\section{The Scope of the Theory: Holistic or Clause-by-Clause?}

But even after we acknowledge that bottom-up reasoning is not reasoning but is at best preparatory to reasoning and that legal reasoning worthy of the name inescapably involves the creation of theories to guide decision, we are left with the question of the appropriate scope of such theories. Must they embrace entire fields of law, such as federal constitutional law or the common law? Must they, perhaps, embrace all of law? Or can they be limited to narrower slices of legal experience, such as particular clauses of the Constitution, or particular statutes, or clusters of related statutes? Can they be so limited even if this results in theories that are not consistent with one another, so that you have clauses sometimes pulling in different directions?

Professor Dworkin answers the last two questions "no." An interpretation of individual clauses that fails to achieve consistency of principle across clauses is illegitimate. A theory of constitutional law must take in the whole Constitution, or at least the whole of the Bill of Rights plus the Fourteenth Amendment-must to that extent be coherent, holistic. ${ }^{18}$ For his basic criticism of Bork is that Bork has no constitutional philosophy. ${ }^{19}$ But as Dworkin well knows, Bork is famous for his theory of free speech, and for his theory of antitrust as well..$^{20}$ And these are very much top-down theories. Bork doesn't go case to case. He derives an overarching principle which he then applies to the cases, discarding many. But his theories are tied to specific provisions; they lack the political and moral generality and ambition that Dworkin prizes. Bork's

18 [T] statement defining which freedoms must be preserved, that is defensible both as a political principle and as consistent with the general form of government established by the Constitution.

Dworkin, Reagan's Justice, NY Rev Books at 30 (cited in note I). Or, as he has put it elsewhere, "[t]he system of [constitutional] rights must be interpreted, so far as possible, as expressing a coherent vision of justice." Ronald Dworkin, Law's Empire 368 (Belknap, 1986). The qualification "so far as possible" enables Dworkin to make room for some pragmatic compromises. See, for example, id at 380-81.

10 "[I] am interested ... . in a different issue: not whether Bork has a persuasive or plausible constitutional philosophy, but whether he has any constitutional philosophy at all." Dworkin, The Bork Nomination, NY Rev Books at 3 (cited in note 1). Bork's "constitutional philosophy is empty: not just impoverished and unattractive but no philosophy at all." Id at 10 . "[H]e believes he has no responsibility to treat the Constitution as an integrated structure of moral and political principles ...." Id. "[H]e has no theory at all, no conservative jurisprudence, but only right-wing dogma to guide his decisions." Id.

${ }^{20}$ The first sentence of Bork's 1971 Indiana Law Journal article begins: "A persistently disturbing aspect of constitutional law is its lack of theory . . ." Bork, 47 Ind $\mathrm{L} \mathrm{J} \mathrm{at} 1$ (cited in note 16). 
only general theory of constitutional law is-distrust of general theory.

The question of the proper scope of a constitutional theory connects with a topic discussed in the preceding debate, about what level of generality of the Framers' intentions should guide judges in interpreting the Constitution..$^{21}$ If you ask what is the intention behind the Equal Protection Clause, you find that it was both to benefit blacks in some ways but not others and to promote an ideal of equality that may be inconsistent with aspects of the more specific intention (for example, that the blacks were entitled only to political, and not to social, equality with whites). The choice of which intention to honor determines for example whether the Supreme Court was correct to outlaw racial segregation in public schools. But it is a question about the level of generality of intention behind a single clause. To pass beyond that to intentions concerning the Constitution as a whole, a sheaf of documents written at different times and covering a variety of discrete topics, is to enter cloudcuckooland. This is not to disparage the holistic approach but to distinguish it from an approach that depends on the Framers' intentions, whether broadly or narrowly construed. Yet it will be a demerit of the holistic approach, in the eyes of many legal professionals, that it cuts free from the Framers' intentions.

\section{IMPLICATIONS FOR ROE $V$ WADE}

The issue of holistic versus clause-by-clause is not merely aesthetic or methodological. Despite the efforts that Dworkin makes to ground Roe $v$ Wade in a particular clause of the Constitution, he cannot have great confidence that the rights he especially cherishes can be generated by theories limited to individual clauses, such as the Due Process Clause, Roe's original home. The substantive construal of that clause stinks in the nostrils of modern liberals and modern conservatives alike, because of its association with Dred Scott's case ${ }^{22}$ (though in fact it played only a small role in that decision) and with Lochner ${ }^{23}$ and the other freedom of contract cases, because of its formlessness, because of its being rather buried in the Fifth Amendment (making one wonder whether it can be all that important-though, granted, it is featured more

21 A topic to which Dworkin has made important contributions. See, for example, Dworkin, Taking Rights Seriously at 134-37 (cited in note 4); Dworkin, A Matter of Principle at 48-50 (cited in note 10); Dworkin, $57 \mathrm{U}$ Chi L Rev at 663-74 (cited in note 1).

22 Scott $v$ Sandford, 60 US (19 How) 393 (1857).

${ }^{23}$ Lochner $v$ New York, 198 US 45 (1905). 
prominently in the Fourteenth Amendment), and because it makes a poor match with the right to notice and hearing that is the procedural content of the clause. If we must go clause by clause in constructing our constitutional theory (actually theories, on this approach), we are conceding, Dworkin must believe, too much rhetorical ammunition to the enemies of the sexual liberty cases.

Could the Ninth Amendment dissolve the tension between the clause-by-clause and holistic approaches? It is a chunk of the text, after all. It says, "The enumeration in the Constitution, of certain rights, shall not be construed to deny or disparage others retained by the people." Could this be a warrant for judges to recognize new rights, both against the federal government and against the states? There is an extensive literature on this question, ${ }^{24}$ but it has had little impact because, with rare exceptions, neither the clause-byclausers nor the holists are happy with basing decisions on the Ninth Amendment. The reason is that the amendment does not identify any of the retained rights, or specify a methodology for identifying them. If it gives the courts anything, it gives them a blank check. Neither the judges nor their academic critics and defenders want judicial review to operate avowedly free of any external criteria. Even "due process" and "equal protection" seem directive compared to the Ninth Amendment-or to "privileges and immunities," another constitutional orphan. So, not only is there not enough textual support for unenumerated constitutional rights, there is too much textual support for them.

The tension between the clause-by-clause approach and the holistic approach is stark in Dworkin's discussion of Roe $v$ Wade. Despite the many insightful and even moving observations that he offers about the abortion problem, ${ }^{25}$ he is not able to find a clause in which the right to an abortion can be made to fit comfortably, though he tries very hard to find one. In his account, as in that of his predecessors in the effort to rationalize the decision, Roe $v$ Wade is the Wandering Jew of constitutional law. It started life in

\footnotetext{
${ }^{24}$ See, for example, Randy E. Barnett, ed, The Rights Retained by the People: The History and Meaning of the Ninth Amendment (George Mason, 1989).

${ }^{25}$ Not all of which I agree with, however. (For the reasons, see my book Sex and Reason ch 10 (Harvard, 1992).) For example, that "a great many abortions took place, before Roe $v$ Wade, in states that prohibited abortion." Dworkin, $59 \mathrm{U}$ Chi L Rev at 411 (cited in note 14); that Catholicism "could not comprehensively change its views about abortion without becoming a significantly different faith," id at 413 ; or that illegal abortions are "dangerous," id at 411. And I don't understand why the Constitution must be interpreted to give conclusive weight to a woman's desire that her fetus die rather than that it be carried to term and turned over "to others to raise and love." Id at 411.
} 
the Due Process Clause, but that made it a substantive due process case and invited a rain of arrows. Laurence Tribe first moved it to the Establishment Clause of the First Amendment, then recanted. ${ }^{26}$ Dworkin now picks up the torch but moves the case into the Free Exercise Clause, where he finds a right of autonomy over essentially religious decisions. ${ }^{27}$ Feminists have tried to squeeze Roe $v$ Wade into the Equal Protection Clause. ${ }^{28}$ Others have tried to move it inside the Ninth Amendment (of course-but if I am right it has no "inside"); still others (including Tribe) inside the Thirteenth Amendment. ${ }^{29}$ I await the day when someone shovels it into the Takings Clause, or the Republican Form of Government Clause (out of which an adventurous judge could excogitate the entire Bill of Rights and the Fourteenth Amendment), or the Privileges and Immunities Clause. It is not, as Dworkin suggests, a matter of the more the merrier; it is a desperate search for an adequate textual home, and it has failed. I cannot adequately explain the reasons for this conclusion here, ${ }^{30}$ but. I will give the flavor of them by glancing briefly at the equal protection argument, which Catharine MacKinnon, ${ }^{31}$ Sylvia Law, ${ }^{32}$ Cass Sunstein, ${ }^{33}$ and others have pressed.

The argument begins by noting that a law forbidding abortions weighs more heavily on women than on men. Granted. But a difference in treatment does not violate the Equal Protection Clause if it is justifiable, and this particular difference in treatment seems, at first glance anyway, justified by the fact that men and women are, by virtue of their biology, differently situated in relation to fetal life. To show that the difference is not substantially related to an important governmental interest, and is therefore unconstitutional under the prevailing standard for reviewing sex dis-

\footnotetext{
${ }^{26}$ See Laurence H. Tribe, American Constitutional Law 1349-50 \& nn 87-88 (Foundation, 2d ed 1988) (acknowledging "shift in the author's thinking" between 1973 and 1978).

${ }^{27}$ Dworkin, $59 \mathrm{U}$ Chi L Rev at 419 (cited in note 14).

${ }^{28}$ See notes 31-33 and accompanying text.

${ }^{29}$ Laurence H. Tribe, The Abortion Funding Conundrum: Inalienable Rights, Affirmative Duties, and the Dilemma of Dependence, 99 Harv L Rev 330, 337 (1985); Andrew Koppelman, Forced Labor: A Thirteenth Amendment Defense of Abortion, 84 Nw U L Rev 480 (1990).

${ }^{30}$ For a fuller discussion, see chapter 12 of my book, Sex and Reason (cited in note 25).

${ }^{31}$ See Catharine MacKinnon, Toward a Feminist Theory of the State 184-94 (Harvard, 1989); Catharine A. MacKinnon, Feminism Unmodified: Discourses on Life and Law 93-102 (Harvard, 1987); Catharine MacKinnon, Reflections on Sex Equality Under Law, 100 Yale L J 1281, 1309-28 (1991).

${ }_{32}$ Sylvia A. Law, Rethinking Sex and the Constitution, 132 U Pa L Rev 955 (1984).

${ }^{33}$ Cass R. Sunstein, Neutrality in Constitutional Law (With Special Reference to Pornography, Abortion, and Surrogacy), 92 Colum L Rev 1 (1992).
} 
crimination challenged under the Fourteenth Amendment, requires consideration of the benefits to the fetus and the costs to others, an intractable inquiry or at least one that the proponents of Roe $v$ Wade do not wish to undertake.

The door to that inquiry cannot be slammed shut by arguing that, whatever justifications might be offered for laws forbidding abortion, the support for those laws in fact comes from people who want to keep women down; and an invidious purpose can condemn a law. Realistically, an invidious purpose can condemn only a trivial law, such as a law imposing a poll tax or requiring a literacy test for prospective voters; courts are not going to deprive the people of essential legal protection just because some of the supporters of such laws (laws criminalizing rape, for example) had bad motives. The principal support for anti-abortion laws, moreover, comes not from misogynists or from "macho" men (Don Juan would favor abortion on demand because it would reduce the cost of sex), but from men and women who, whether or not Roman Catholic (many of them of course are Roman Catholic), believe on religious grounds in the sanctity of fetal life. That is not a sexist or otherwise discriminatory or invidious belief, even though it is positively correlated with a belief in the traditional role of women, a role that feminists, with much support in history, consider subordinate. No doubt for many opponents of abortion, opposition to abortion is commingled with opposition to a broader set of practices and values-call it feminism. But for many supporters, abortion on demand is the very symbol of feminism. Should the courts take sides in this clash of symbols?

Behind symbols, ideology, even religious belief may lie concrete interests. The debate over abortion, and over the sexual and reproductive freedom of women more broadly, is in part a debate between women who lose and women who gain from that freedom. The sexually freer that women are, the less interest men have in marriage, and women specialized in household rather than market production are therefore harmed. This is a clash of interests, and in a democratic system legislatures rather than courts are generally considered the proper arenas for resolving such clashes.

Dworkin takes a different tack. He considers a person's view of the sanctity of life a religious view even if the person is an atheist; and he says that the government cannot, without violating the Free Exercise Clause, make a person act on one religious view rather than another. Well, fine, but if "religion" is to be understood so broadly, then we must allow for a religion of free markets (economic freedom is a religion to Murray Rothbard, Milton and 
David Friedman, Friedrich Hayek, Ayn Rand, Richard Epstein, and perhaps even Robert Nozick, whom, by the way, Dworkin has acknowledged as a fellow liberal ${ }^{34}$ ), a religion of animal rights, of environmentalism, of art, and so on. An ordinance that forbade an aesthete to alter the exterior of his landmark house would thus be an infringement of religious freedom. Dworkin's expansive notion of religion actually dissolves the distinction he wants to draw between restrictions on abortion and other restrictions on personal freedom.

Dworkin is able to make abortion a matter of the varying opinions that Americans hold about the sanctity of life, rather than an issue of life or death, only because he will not allow states to define the fetus as a person and therefore abortion as murder. (If he did allow this, he would not be able to distinguish abortion from infanticide.) Yet the states are allowed to decide what is property and (in the case of prisoners for example) what is liberty, for purposes of the Due Process Clause; why not what is a person? Can't a state decide that death means brain death rather than a stopped heart? And if it can decide when life ends why can't it decide when life begins? Here by the way is an illustration of one of the modest functions I assigned earlier to bottom-up reasoning, that of testing the consistency of our thought.

An Illinois statute makes abortion murder, ${ }^{35}$ and on the civil side wrongful death. ${ }^{36}$ The Supremacy Clause prevents its application to abortions privileged by Roe $v$ Wade, but with that qualification the constitutionality of the statute cannot be doubted. It shows that the states are already in the business of defining human life. They can, thus, classify a fetus as a human being, and the question is then-because I do not think the state's declaration of personhood should be conclusive (what if it declared a meat loaf a person?) - the strength of the state's interest in protecting that newly recognized human being against various menaces to it.

Quite apart from the specific objections that can be made to Dworkin's attempt to ground a right of abortion in the Free Exercise Clause, it blurs his holistic approach. There is no actual inconsistency, because his interpretation of the Free Exercise Clause draws on values derived from his reflections on other provisions in the Constitution, consistent with his insistence on the integrity of

34 See Bryan Magee, Thrée Concepts of Liberalism: A Conversation with Ronald Dworkin, New Republic 41, 47 (Apr 14, 1979).

35 Homicide of an Unborn Child, Ill Rev Stat ch 38, i 9-1.2 (1989).

${ }^{36}$ Wrongful Death Act, id at ch $70, \pi 2.2$. 
the document as a whole. But his position would be clearer, and I think more persuasive, if he were content to derive a right of abortion from his general theory of constitutional law, in which the clauses merge and lose their distinctness and the issue of the right of abortion becomes the place of such a right in the liberal theory of the state-and I agree that it has the place in that theory that Dworkin assigns to it. Griswold, the first of the sexual liberty cases, actually started down this road. For we recall how Justice Douglas, albeit in his usual slipshod way, tried to extract a general (or at least generalizable) principle of sexual liberty from a collection of seemingly unrelated constitutional clauses..$^{37}$ But no judge has picked up this particular spear and tried to throw it farther.

\section{A Role For Conscience; A Basis in Fact}

The arguments against the holistic approach are familiar. The basic one is that it gives judges in a democracy (perhaps in any polity) too much discretion. When you think of all those constitutional theories jostling one another-Epstein's that would repeal the New Deal, Ackerman's and Sunstein's that would constitutionalize it, Michelman's that would constitutionalize the platform of the Democratic Party, Tushnet's that would make the Constitution a charter of socialism, Ely's that would resurrect Earl Warren, and some that would mold constitutional law to the Thomists' version of natural law-you see the range of choice that the approach legitimizes and, as a result, the instability of constitutional doctrine that it portends. It is no good saying that Epstein is wrong, or Michelman is wrong, or St. Thomas is wrong; the intellectual tools do not exist for administering a death blow to these theories (to all of them, at any rate). Logic, science, statistical inquiry, the lessons of history, shared intuitions-none of these techniques of either exact or practical reasoning can slay them, or even wound them seriously in the eyes of those drawn to them for reasons of temperament or personal experience. If the only constraints on constitutional decisionmaking are good arguments, the embarrassment is the number and strength of good arguments on both sides-on many sides-of the hot issues.

Heat is important here. If you're indifferent to the outcome of a dispute, you'll weigh up the arguments on both sides and give the nod to the side that has the stronger arguments, even if the weaker side has good arguments too. But if you have a strong emotional

37 Griswold, 381 US at 484-86. 
commitment to one side or another, it would be not only unnatural, but imprudent, to abandon your commitment on the basis of a slight, or even a not so slight, preponderance of arguments against your side. Our deepest commitments are not so weakly held. Hence there can be practical indeterminacy about an issue even if a disinterested observer would not think the competing arguments evenly balanced..$^{38}$

A comprehensive theory of constitutional law is apt to step on the toes of many deeply held commitments without being supportable by decisive arguments. That is why the situation with respect to constitutional theory is one of practical indeterminacy, driving the cautious jurist back into the clause-by-clause approach. It is much easier to impute a purpose to a particular clause and then use that purpose both to generate and circumscribe the meaning of the clause-which is all I meant in speaking of Bork's "theories" of free speech and of antitrust-than to impute a purpose to the Constitution as a whole. The problem with the modest approach is that it opens up large gaps in constitutional protection. As the eighteenth century recedes, and the original text becomes a palimpsest overlaid with the amendments of two centuries, not only the vision but the very identity of the Founders blurs and by going clause by clause one could end up with a document that gave answers only to questions that no one was asking any longer. Americans like to think that the Constitution protects them even against political enormities that don't fit comfortably into one clause or another. This is the practical appeal of an approach that makes of the Constitution a tire that seals up automatically when it is punctured or gashed. In 1791 such an approach might well have been otiose; the modest top-down, the ambitious top-down, the bottomup approaches might all have coincided. No more. They diverge further with every passing year, and the ambitious top-down approach becomes more attractive with every passing year. It is not just academic fashion that has made constitutional theorizing a bigger activity today than a century ago.

I would abandon, however, as too ambitious, too risky, too contentious, the task of fashioning a comprehensive theory of constitutional law, an "immodest" top-down theory intended to guide judges. $^{39}$ At the same time I would allow judges to stretch clauses-even such questionable candidates as the Due Process

\footnotetext{
38 See Posner, The Problems of Jurisprudence at 124-25 (cited in note 11).

39 The qualification "theory intended to guide judges" is vital. Academic theories have academic value, and can moreover point to or highlight facts that can alter judges' thinking,
} 
Clause-when there is a compelling practical case for intervention. This was Holmes's approach, and later that of Cardozo, Frankfurter, and the second Harlan. Holmes said (privately, to be sure) that a law was constitutional unless it made him want to "puke."40 If we follow this approach we must be careful not to appoint judges whose stomachs are too weak. Of course he was not speaking literally; nor am I. The point is only that our deepest values (Holmes's "can't helps"41) live below thought and provide warrants for action even when we cannot give those values a compelling or perhaps any rational justification. This point holds even for judicial action-although I may think this only because it makes a judge happier in his job. He knows that he won't have to ratify a law or other official act or practice that he deeply feels to be terribly unjust, even if the conventional legal materials seem not quite up to the job of constitutional condemnation. He preserves a role for conscience.

It is easy for legal professionals and intellectuals of every stripe to ridicule this approach-which, by the way, transcends both top-down and bottom-up reasoning by locating a ground for judicial action in instinct rather than in analysis. They can ridicule it for its shapelessness (shades of substantive due process!), its subjectivity, its noncognitivism, its relativism, its foundationlessness, its undemocratic character unredeemed by pedigree or principle. But the alternatives are unpalatable (to continue the digestive metaphor); and maybe what was good enough for Holmes should be good enough for us. And it need not, perhaps-this alternative approach that I am discussing-be quite as shapeless, as subjective, as visceral as I have implied. Certainly it need not be inarticulate (in this respect the digestive metaphor is inapt); Holmes was the most eloquent judge in the history of this country, perhaps of any country. And it can be-it should be-informed through empirical inquiry more searching than is normal in judicial opinions. Simple prudence dictates that before you react strongly to some-

just as economic theory can help us interpret the recent events in eastern Europe and the Soviet Union as a refutation of socialism.

10 See Philippa Strum, Louis D. Brandeis: Justice for the People 361 (Harvard, 1984) ("[Justice Brandeis] told [his law clerks] that Justice Holmes employed a simple rule of thumb for judging the constitutionality of statutes, summed up in Holmes's question, 'Does it make you puke?" ").

${ }^{11}$ See Letter of Oliver Wendell Holmes, Jr., to Harold J. Laski (Jan 11, 1929), in Mark DeWolfe Howe, ed, 2 Holmes-Laski Letters 1124 (Harvard, 1953) ("when I say that a thing is true I only mean that I can't help believing it-but I have no grounds for assuming that my can't helps are cosmic can't helps"). 
thing you try to obtain as clear an idea as possible of what that something is.

The Griswold case, for example, in part because of the excellent brief of the lawyers for the birth control clinic (one of whom was Thomas Emerson of the Yale Law School faculty), provided an opportunity-which the Court didn't take-to deploy pertinent data in support of a professionally more respectable precedent than what emerged from Douglas's majority opinion and the concurrences. The brief highlights some striking facts which subsequent research ${ }^{42}$ has confirmed. One is that statutes forbidding contraceptives had been passed in a wave in the late nineteenth century but had been repealed in all but two states, Connecticut and Massachusetts, in both of which repeal, though repeatedly attempted, had been blocked by the vigorous lobbying of the Catholic Church working on the large Catholic population in both states. But while the statute had remained on the books, the only efforts to enforce it-and they were entirely successful-were directed against birth control clinics, whose clientele was dominated by the poor and the uneducated; middle-class women preferred to go to their private gynecologist for contraceptive advice and devices. So the clinics were closed down and of course abortion was illegal at the time, making the sexual and reproductive dilemmas of poor women acute, while middle-class women had unrestricted access to contraceptives, and probably to safe illegal abortions as well if contraception failed, but it was less likely to fail for them.

And remember that the law made no distinction between married and unmarried persons; it could be thought therefore to burden marriage-specifically marriage by the poor and the working class-and to do so arbitrarily. The law had been founded on Protestant (indeed, such are the ironies of history, on anti-Catholic) concern with fornication, adultery, and prostitution, and with the immorality of immigrants and of the lower class generally, though it may actually have discouraged marriage-and fostered immorality-among the poor; and its survival owed everything to a belief, by 1965 limited essentially to Catholics and by no means shared by all of them, that it is sinful to impede the procreative outcome of an act of sexual intercourse.

The law, in sum, was sectarian in motive and rationale, capriciously enforced, out of step with dominant public opinion in the country, genuinely oppressive, and, I think it fair to say, a national

42 See my discussion in chapters 7 and 12 of Sex and Reason (cited in note 25). 
embarrassment-as would be a law forbidding remarriage, or limiting the number of children a married couple may have, or requiring the sterilization of persons having genetic defects, or denying the mothers of illegitimate children parental rights, or forbidding homosexuals to practice medicine, or forbidding abortion even when necessary to spare a woman from a crippling or debilitating illness, or requiring the tattooing of people who carry the AIDS virus, or-coming closest to Griswold itself-requiring married couples to have a minimum number of children unless they prove they're infertile. It is not the worst thing in the world to have judges who are willing to strike down such laws in the name of the Constitution. The sequelae to Griswold show that the risks in this approach are enormous too, but smaller I think than the risks that would be entailed by the totalizing approach that Professor Dworkin defends with such elegant tenacity.

Dworkin believes that only his approach can prevent constitutional doctrine from changing with every change in the composition of the Court. This exaggerates both the possibility of cogent theorizing at the high level of abstraction implied by the holistic approach and the fidelity of judges, especially Supreme Court Justices, whose decisions are unreviewable, to the doctrines (as distinct from narrow holdings) of their predecessors. Nothing but force majeure can prevent judges from giving vent to their political and personal values, if that is what they want to do.

I remind you, in support of my suggested approach, that judicial decision precedes articulate theory-because the duty to resolve the dispute at hand is primary-that few judges (few anybody) are equipped to create or even evaluate comprehensive political theories, that our judges are generally not appointed on the basis of their intellectual merit, and that instinct can be a surer guide to action than half-baked intellectualizing. I know that I seem to be indulging in paradox in proposing an approach that accepts the role of personal values in adjudication and asks only that they be yoked to empirical data. This may seem a strange match indeed. But personal values, while influenced by temperament and upbringing, are not independent of adult personal experience; and research-into facts, not into what judges have said in the past-can be a substitute for experience, can bring home to a judge the realities of a law against contraception or against abortion or against sodomy. That at least has been my own experience. It may not be typical. Yet I think it is apparent that most judges can handle facts better than they can handle theories. Of course that is what bottom-up reasoners say in defense of their approach. 
Bottom-up reasoning pretends, however, to be-reasoning. I ask you to join with me in abandoning that pretense.

In doing so we will make room for the greatest judge in the history of our law, and probably the greatest scholar. I refer of course to Holmes-who also had the finest philosophical mind in the history of judging. His most famous judicial opinion is his dissent in Lochner. ${ }^{43}$ But, judged by the usual principles of legal reasoning, it is a flop, because it illustrates Holmes's inveterate tendency "to substitute epigrams for analysis: instead of taking Lochner as the opportunity to show what the due process clause was all about, Holmes contented himself with the smug assertion that the clause did not 'enact Mr. Herbert Spencer's Social Statics." "44 I agree: "It is not, in short, a good judicial opinion. It is merely the greatest judicial opinion of the last hundred years."45 There is something wrong with the conventional principles of legal reasoning. They miss the vital essence of legal growth and insight.

I remind you finally that I am speaking primarily of areas of constitutional law in which constitutional history and text give out. In an area such as freedom of speech, where we have a text and a history and a long case experience, the materials are at hand for the creation of a theory, albeit clause-bound, that will guide future decisions; and so, perhaps, with such questions as whether and what types of sex discrimination fall under the ban of the Equal Protection Clause. ${ }^{46}$ In areas to which the constitutional text and history and a long decisional tradition cannot fairly be made to speak, such as that of sexual rights, we must either renounce a judicial role or suffer the judges to fall back on their personal values enlightened so far as they may be by a careful study of the pertinent social phenomena. Neither top-down nor bottom-up legal reasoning can finesse this painful choice.

13198 US at 74.

4 David P. Currie, The Constitution in the Supreme Court: The Second Century: 1888-1986 82 (Chicago, 1990). See also id at 81-82, 130.

45 Richard A. Posner, Law and Literature: A Misunderstood Relation 285 (Harvard, 1988).

16 There are, of course, many areas outside of constitutional law where field-specific theories are entirely feasible: torts, contracts, and antitrust are examples. 


\section{INTERDISCIPLINARY APPROACHES}


HeinOnline -- 59 U. Chi. L. Rev. 4521992 